\title{
Peningkatan Hasil Belajar Siswa Kelas IV pada Pembelajaran IPA dengan Model Pembelajaran Make A Match Di SDN 12 Api-Api Pesisir Selatan
}

Donni Saputra

SDN 12 Api-Api Kecamatan Bayang Pesisir Selatan

$\risingdotseq$ e-mail: donnisaputra11@yahoo.com

\begin{abstract}
The purpose of this study was to describe the improvement of student learning outcomes IPA with Model make a match at SDN 12 Api-Api. This type of research is the Classroom Action Research (PTK) is conducted in two cycles. The data source is the fourth grade students of SDN 12 Api-Api numbered 17 people. The instrument used in this study is the assessment sheet affective student, teacher activity sheet and test the students' understanding. Based on analysis of the affective ratings of students In the first cycle the change in student behavior responsibilities increased $51.0 \%$ to $83.3 \%$ in the second cycle and the change in behavior of the cooperation of students in the first cycle of $44.1 \%$ increased to $74.5 \%$ in the second cycle. The results of cognitive learning that an understanding had also increased. In the first cycle student comprehension $58.8 \%$ increase to 82.4 in the second cycle. From the data obtained it can be concluded that there is a learning outcome IPA fourth grade students of SDN 12 Api-Api after using the model make a match.
\end{abstract}

Keyword: learning outcomes, IPA, model make a match

Copyright (C) 2017 IICET (Indonesia) - All Rights Reserved

Indonesian Institute for Counseling, Education and Therapy (IICET)

\section{PENDAHULUAN}

Dalam dunia pendidikan, guru adalah seorang pendidik, pembimbing, pelatih, dan pengembangan kurikulum yang dapat menciptakan kondisi dan suasana pembelajaran yang kondusif, yaitu suasana belajar yang menyenangkan, menarik, memberi rasa aman, memberikan ruang pada siswa untuk berpikir aktif, dan kreatif. Salah satu masalah yang dihadapi dunia pendidikan saat ini adalah masalah lemahnya pelaksanaan proses pembelajaran yang diterapkan pada guru di sekolah. Proses pembelajaran yang terjadi selama ini kurang mampu mengembangkan kemampuan siswa.

Menurut Susanto (2013:167), "IPA adalah usaha sadar manusia dalam memahami alam semesta melalui pengamatan yang tepat pada sasaran, serta menggunakan prosedur, dan dijelaskan dengan penalaran sehingga mendapatkan suatu kesimpulan". Untuk menyampaikan materi pembelajaran IPA dalam Proses Belajar Mengajar (PBM) di sekolah diperlukan model pembelajaran yang bervariasi dan menyenangkan sehingga siswa tidak menjadi bosan. Selain itu guru juga harus menguasai materi dan mampu mengajarkan siswa dalam memberikan berbagai pengalaman baru.

Berdasarkan hasil observasi yang peneliti lakukan, pada saat pembelajaran berlangsung, guru menyampaikan materi pelajaran dengan metode ceramah di depan kelas. Peneliti melihat bahwa dalam proses pembelajaran, siswa melakukan pengamatan terhadap gambar yang ada di buku, kemudian guru langsung menyampaikan materi di depan kelas dan selanjutnya siswa diminta untuk menjawab pertanyaan yang ada di buku. Siswa hanya menerima apa yang disampaikan oleh guru dan siswa belum terlibat dalam proses pembelajaran yang berlangsung. 
Kendala lain yang dialami guru dalam pembelajaran adalah kurangnya kerjasama siswa jika guru menugaskan mereka untuk bekerja kelompok dan siswa juga kurang bertanggung jawab dengan pekerjaan atau tugas yang diberikan oleh guru karena siswa lebih senang meribut dan sibuk dengan urusan mereka sendiri. Untuk mengatasi masalah di atas, peneliti berusaha untuk memperbaiki proses pembelajaran dengan memilih model pembelajaran yang tepat sehingga masalah tersebut dapat diatasi dan tujuan pembelajaran dapat dicapai. Salah satu model pembelajaran yang mampu mengembangkan keterampilan berpikir peserta didik, kreatifitas berpikir siswa inovatif. dalam memecahkan masalah adalah Make A Match.

Fenomena seperti ini tentu kurang baik, jadi sangat dirasakan perlu untuk mencari alternatif pemecahan masalah, salah satunya dengan menggunakan model pembelajaran yang dapat meningkatkan hasil belajar siswa dalam proses pembelajaran IPA, yaitu Make A Match. Sesuai dengan rumusan masalah, maka tujuan penelitian ini adalah: Untuk mendeskripsikan peningkatan hasil belajar ranah kognitif pengetahuan dan pemahaman siswa, untuk mendeskripsikan peningkatan hasil belajar ranah afektif tanggung jawab dan kerja sama siswa kelas IV pada pembelajaran IPA dengan menggunakan model Make A Match di SD Negeri 12 Api-Api.

\section{METODOLOGI}

Jenis penelitian yang digunakan adalah Penelitian Tindakan Kelas (PTK). Menurut Wardhani, dkk. (2008:14), "PTK adalah penelitian yang dilakukan oleh guru di dalam kelasnya sendiri melalui refleksi diri, dengan tujuan untuk memperbaiki kinerjanya sebagai seorang guru, sehingga hasil belajar siswa meningkat". Penelitian ini dilakukan di kelas IV SDN Api-Api, pada tahun ajaran 2015/2016. Subjek penelitian ini adalah siswa kelas IV SDN 12 Api-Api yang berjumlah 17 orang. Penelitian ini akan dilaksanakan pada semester II tahun ajaran 2015/2016.

Penelitian ini dilakukan dengan mengacu pada desain PTK yang dirumuskan Arikunto, dkk. (2010:16) yang terdiri dari empat komponen, yaitu: perencanaan, pelaksanaan tindakan, pengamatan/observasi, dan refleksi. ndikator keberhasilan pada penelitian adalah presentase hasil pembelajaran siswa sudah masuk dalam kategori baik dan sangat baik $(>70 \%)$ untuk indikator positif,dan kategori kurang dan sangat kurang $(<30 \%)$ indikator negatif.siswa dikatakan apabila telah mencapai acuan standar kriteria ketuntasan minimal (KKM) yang ditetapkan oleh sekolah tempat penelitian yaitu 70 .

Data dalam penelitian ini berupa data kualitatif. Sumber data penelitian adalah proses kegiatan belajar yang meliputi perencanaan pembelajaran, pelaksanaan pembelajaran, evaluasi pembelajaran, perilaku guru dan siswa waktu pembelajaran berlangsung. Data penelitian ini dikumpulkan dengan menggunakan beberapa teknik sebagai berikut: (1) Observasi, (2) Tes, dan (3) Dokumentasi.

Dalam penelitian ini, peneliti menggunakan beberapa instrumen untuk mengumpulkan data, yaitu: (1) Lembar observasi kegiatan guru, (2) Lembar tes akhir siklus, dan (3) Lembar observasi penilaian afektif siswa. Data yang diperoleh dalam penelitian dianalisis dengan menggunakan analisis data kualitatif dan kuantitatif. Analisis data kualitatif adalah analisis data yang dimulai dengan menelaah sejak pengumpulan data sampai seluruh data terkumpul.

\section{HASIL DAN PEMBAHASAN \\ Deskripsi Siklus 1}

Data hasil observasi proses pelaksanaan Guru dalam pembelajaran IPA

Berdasarkan lembar observasi proses pelaksanaan pembelajaran guru dalam pembelajaran IPA pada siklus I, maka jumlah skor dan persentase proses pelaksanaan pembelajaran guru dalam menngelola pembelajaran pada siklus I terdapat pada dilihat pada tabel berikut: 
Tabel 1. Persentase Kegiatan Guru dalam Pembelajaran IPA dengan Model Make a Match Siswa Kelas IV SDN 12 Api-Api

\begin{tabular}{cccc}
\hline Pertemuan & Jumlah Skor & \% & Kategori \\
\hline I & 8 & 53,3 & Kurang baik \\
II & 9 & 60 & Cukup baik \\
Rata-rata & & 56,6 & Kurang baik \\
\multicolumn{1}{r}{ Target } & & & 70 \\
\hline
\end{tabular}

Analisis pada persentase guru dalam mengelola pembelajaran memiliki rata-rata persentase $56,6 \%$ sehingga dapat dikategorikan kurang baik. Hal ini disebabkan karena guru belum melakukan keseluruhan indikator kegiatan guru yang telah ditetapkan dalam proses pembelajaran IPA serta kurang mampunya guru dalam mengelola kelas dengan baik. Oleh karna itu guru akan mengusahakan agar pada siklus II untuk memperbaiki kekurangan yang terjadi pada siklus I.

\section{Data Hasil Belajar Ranah Kognitif}

Berdasarkan hasil tes akhir siklus I, persentase siswa yang tuntas dan rata-rata nilai tesnya dapat dilihat pada tabel berikut:

Tabel 2. Ketuntasan dan Rata-Rata Hasil Belajar Siswa (Ujian Akhir Siklus) Siklus I

\begin{tabular}{ccc}
\hline Uraian & Jumlah & Target \\
\hline Siswa yang mengikuti tes & 17 & - \\
Siswa yang tuntas belajar & 10 & - \\
Siswa yang tidak tuntas belajar & 7 & - \\
Persentase ketuntasan tes akhir siklus I & 58,8 & 70 \\
Rerata nilai tes akhir siklus I & 67,4 & 70 \\
\hline
\end{tabular}

Dapat dilihat bahwa dari 17 orang siswa yang mengikuti tes hanya 10 orang siswa $(58,8 \%)$ yang mendapat nilai di atas KKM. Sedangkan siswa yang tidak tuntas atau di bawah KKM sebanyak 7 orang siswa $(41,1 \%)$. Terlihat bahwa persentase ketuntasan hasil belajar siswa pada ujian akhir siklus secara keseluruhan masih tergolong rendah, ini menandakan bahwa pemahaman siswa terhadap materi pembelajaran IPA masih kurang. Dan ini belum bisa mencapai target hasil belajar yang ditetapkan dalam indikator keberhasilan yaitu $70 \mathrm{KKM}$

\section{Data Hasil Penilaian Ranah Afektif Siswa}

Data hasil penilaian ranah afektif siswa dapat dilihat melalui lembar penilaian ranah afektif siswa dan dapat digunakan untuk melihat proses dan perkembangan siswa yang terjadi selama pembelajaran berlangsung. Hasil analisis observer terhadap penilaian afektif siswa dalam pembelajaran dapat dilihat pada dapat dilihat pada ( Lampiran V halaman 97- 100) tabel berikut:

Tabel 3. Jumlah dan Persentase Ranah Afektif Siswa dalam Pembelajaran IPA Dengan Model Make A Match Kelas IV SDN 12 Api-Api Siklus I

\begin{tabular}{ccccccc}
\hline Pertemuan & Jumlah yang tuntas & \% & $\begin{array}{c}\text { Jumlah siswa yang } \\
\text { belum tuntas }\end{array}$ & $\begin{array}{c}\text { \% } \\
\text { Rata-rata hasil } \\
\text { belajar }\end{array}$ \\
\hline I & 9 & 53 & 8 & 47 & 64 \\
II & 11 & 65 & 6 & 35 & 70 \\
Jumlah siklus I & 20 & & 14 & & 134 \\
Rata-rata siklus I & 10 & 59 & 7 & 41 & 67 \\
\hline
\end{tabular}

Dapat dikemukakan hasil belajar afektif siswa pada bagian yang diamati dan penjelasannya sebagai berikut: (a) Pertemuan I siswa tuntas 9 orang de-ngan persentase 53\% siswa yang tidak tuntas 8 orang persentase $47 \%$ dengan rata-rata hasil belajar afektif 64, (b) Pertemuan II siswa yang tuntas 11 orang dengan 
persentase $65 \%$ jumlah siswa yang tidak tuntas 6 orang dengan persentase $35 \%$ dengan rata-rata hasil belajar afektif 70, dan (c) Rata-rata pada siklus I pertemuan I dan II jumlah siswa yang tuntas 10 orang dengan persentase $59 \%$ sedangkan jumlah siswa yang belum tuntas 7 orang dengan persentase $41 \%$ dengan rata-rata hasil belajar 67.

Pada siklus I ini terlihat masih banyak siswa yang tidak tuntas dalam penilaian afektif dalam proses pembejaran IPA. Hal ini disebabkan model yang digunakan guru sangatlah berbeda dengan sebelumnya, model yang digunakan oleh guru dalam proses pembelajaran IPA masih baru, sehingga siswa masih belum mengerti dalam penerapan model make a match dalam proses pembelajaran IPA.

\section{Deskripsi Kegiatan Pembelajaran Siklus II}

Lembar observasi kegiatan pembelajaran (dari aspek Guru)

Berdasarkan lembar observasi kegiatan guru dalam pembelajaran pada siklus II, maka jumlah skor dan persentase kegiatan guru dalam mengelola pembelajaran pada siklus II.

Tabel 4. Persentase Hasil Observasi Kegiatan Guru Pada Siklus II

\begin{tabular}{|c|c|c|c|}
\hline Pertemuan & Jumlah Skor & $\%$ & Kategori \\
\hline I & 11 & 73,3 & Baik \\
\hline II & 12 & 80 & Sangat Baik \\
\hline Rerata & & 76,7 & Baik \\
\hline \multicolumn{2}{|c|}{ Target } & & \\
\hline
\end{tabular}

Persentase kegiatan guru dalam mengelola pembelajaran memiliki rata-rata persentase 76,7\%. Dengan demikian, guru dalam mengelola pembelajaran sudah dikatakan baik dan persentase guru dalam mengelola pembelajaran sudah jauh meningkat dari siklus sebelumnya. Hal ini disebabkan karna guru sudah melakukan keseluruhan indikator kegiatan guru yang telah ditetapkan dalam pembelajaran ipa pada model pembealajaran make a match.

\section{Hasil Belajar Siswa}

Berdasarkan hasil tes akhir siklus II, persentase siswa yang tuntas dan rata-rata nilai tesnya dapat dilihat pada tabel berikut:

Tabel 5. Persentase Hasil Belajar Siswa pada Siklus II

\begin{tabular}{ccc}
\hline Uraian & Jumlah & Target \\
\hline Siswa yang mengikuti tes & 17 & - \\
Siswa yang tuntas belajar & 14 & - \\
Siswa yang tidak tuntas belajar & 3 & - \\
Persentase ketuntasan tes akhir siklus II & $82,4 \%$ & $70 \%$ \\
Rerata nilai tes akhir siklus II & 74,7 & 70 \\
\hline
\end{tabular}

Dari 17 orang siswa yang mengikuti tes hanya 14 orang siswa $(82,4 \%)$ yang mendapat nilai di atas KKM. Sedangkan siswa yang tidak tuntas atau di bawah KKM sebanyak 3 orang siswa (17,6\%). Dengan demikian, hal ini berarti hasil belajar yang ditetapkan dalam indikator keberhasilan yaitu 70\% sudah tercapai. Hal ini disebabkan karna meningkatnya aktivitas yang dilakukan siswa dalam proses pembelajaran sehingga materi pelajaran dapat dipahami siswa dan guru juga melakukan appersepsi sebelum ulangan harian dimulai.

\section{Hasil Penilaian Ranah Afektif Siswa dalam Pembelajaran}

Data observasi penilaian ranah afektif siswa dalam pembelajaran siklus II dengan indikator penilaian ranah afektif adalah siswa aktif mengemukakan pendapat dan siswa mampu mencocokan kartu pasangan. 


\section{Tabel 6. Jumlah dan Persentase Ranah Afektif Siswa (tanggung jawab dan kerja sama) dalam Pembelajaran IPAdengan Model Make A Match Kelas IV SDN 12 Api-Api Pada Siklus II}

\begin{tabular}{lccccc}
\hline No & Sik lus & $\begin{array}{c}\text { Persentase Tanggung } \\
\text { Jawab }\end{array}$ & Kategori & $\begin{array}{c}\text { Persen tase } \\
\text { Kerjasama }\end{array}$ & Kategori \\
\hline $\mathbf{1}$ & I & $78.4 \%$ & Cukup & $59.7 \%$ & Kurang \\
$\mathbf{2}$ & II & $82.3 \%$ & Baik & $80.4 \%$ & Baik \\
Rata-rata & $80 \%$ & Cukup & $70 \%$ & Cukup \\
\hline
\end{tabular}

Rerata persentase afektif siswa tanggung jawab dan kerja sama pada siklus II adalah: (1) Pada siklus I persentase tanggung jawab 78,4 \% kategori cukup baik berarti cukup baik jika setengah pekerjaan diseleseikan pada waktu yang ditentukan dengan rata-rata hasil belajar80 \%, (2) Pada siklus II persentase tanggung jawab 82,3\% kategori cukup baik jika setengah pekerjaan diseleseikan pada waktu yang ditentukan dengan persentase $82.3 \%$ dengan rata-rata hasil belajar $80 \%$, (3) Pada siklus I persentase kerja sama $59.7 \%$ kategori kurang baik berarti kurang jika sebagian kecil pekerjaan diseleseikan pada yang ditentukan.dengan rata-rata hasil belajar 70\%, dan (4) Pada siklus II persentase kerja sama $80.4 \%$ kategori baik berarti baik jika semua pekerjaan diseleseikan pada waktu yang ditentukan dengan rata-rata hasil belajar ranah afektif siswa $70 \%$.

Secara umum penilaian afektif siswa sudah terjadi peningkatan dibandingkan dengan siklus I. Berdasarkan peningkatan ini, berarti target penelitian afektif sudah tercapai. Hal tersebut karna siswa sudah terbiasa dalam proses pembelajaran dengan menggunakan model make a matchserta guru juga menampilkan media pembelajaran, sehingga siswa lebih kreatif berfikir dan hasil belajar meningkat.

\section{Pembahasan}

\section{Kegiatan Guru Pada Siklus I dan Siklus II}

Persentase rata-rata aktivitas guru dalam proses pelaksanaan pembelajaran terjadi peningkatan dengan penggunaan model Make A Match. dapat dilihat pada tabel dibawah ini:

Tabel 7. Persentase aktivitas guru dalam proses pelaksanaan pembelajaran pada silus I dan siklus II

\begin{tabular}{ccc}
\hline Siklus & $\%$ & Kategori \\
\hline I & 56,6 & Kurang Baik \\
II & 76,7 & Baik \\
\hline
\end{tabular}

Disimpulkan bahwa pelaksanaan pembelajaran dengan penggunaan model Make A Matchdapat meningkatkan aktifitas guru dalam proses pelaksannaan pembelajaran. Hal ini terlihat adanya peningkatan persentase aktivitas guru dalam proses pelaksanaan pembelajaran dari siklus I ke siklus IImengalami peningkatan dari 56,6 \% menjadis 76,7 \%. Peningkatan aktifitas guru dalam proses pelaksanaan pembelajaran disebabkan peneliti sudah bisa melaksanakan pembelajaran IPA dengan penggunaan model Make A Matchserta melakasnakan pembelajaran sesuai RPPdan meggunakan media pembelajaran sehingga proses pembelajaran berlangsung baik.

\section{Hasil Belajar Siswa Pada Siklus I dan Siklus II}

Data mengenai hasil belajar siswa diperoleh melalui tes hasil belajar di akhir siklus. Dalam hal ini terlihat peningkatan ketuntasan hasil belajar dari siklus I ke siklus II pada tabel berikut:

Tabel 8. Rata-rata Ketuntasan Hasil Belajar Siklus I dan Siklus II

\begin{tabular}{ccccc}
\hline Siklus & $\begin{array}{c}\text { Persentase dan } \\
\text { jumlah } \\
\text { Siswa yang }\end{array}$ & $\begin{array}{c}\text { Persentase dan } \\
\text { jumlah siswa yang } \\
\text { belum mencapai }\end{array}$ & $\begin{array}{c}\text { Rata- rata secara } \\
\text { klasikal }\end{array}$ & Keterangan \\
\hline
\end{tabular}




\begin{tabular}{|c|c|c|c|c|}
\hline & mencapai $>70$ & nilai $>70$ & & \\
\hline I & $\begin{aligned} & 58,8 \% \\
= & 10 \text { orang }\end{aligned}$ & $\begin{aligned} & 41,2 \% \\
= & 7 \text { orang }\end{aligned}$ & 67,4 & \multirow{2}{*}{$\begin{array}{l}\text { Persentase hasil belajar siswa } \\
\text { mengalami peningkatan } 23,5 \%\end{array}$} \\
\hline II & $\begin{aligned} & 82,3 \% \\
&= 14 \text { orang } \\
&\end{aligned}$ & $\begin{aligned} & 17,6 \% \\
&= 3 \text { orang } \\
&\end{aligned}$ & 74,7 & \\
\hline
\end{tabular}

Pada siklus I, siswa yang tuntas belajar ada 10 orang $(58,8 \%)$, dan yang belum tuntas belajar 7 orang $(41,2 \%)$, dengan nilai rata- rata secara klasikal $67,4 \%$. sedangkan pada siklus II, siswa yang tuntas belajar ada 14 orang $(82,3 \%)$, dan yang belum tuntas belajar ada 3 orang $(17,6 \%)$ dengan nilai rata-rata secara klasikal 74,7 \%. Dengan demikian dapat disimpulkan, bahwa persentase belajar siswa dari siklus I ke siklus II mengalami peningkatan sebesar $23,5 \%$, sedangkan untuk nilai rata-rata hasil belajar secara klasikal juga mengalami peningkatan dan sudah mencapai standar nilai KKM.

\section{Penilaian Ranah Afektif Siswa Pada Siklus I dan Siklus II}

Tabel 9. Persentase Rata-rata Afektif Siswa Kelas IV dalam Pembalajaran IPA melalui Model Pembelajaran Model Make a Match pada Siklus I dan Siklus II

\begin{tabular}{cccccc}
\hline No & Siklus & $\begin{array}{c}\text { Persentase Tanggung } \\
\text { Jawab }\end{array}$ & Kategori & Persentase Kerjasama & Kategori \\
\hline $\mathbf{1}$ & I & $78.4 \%$ & Cukup & $59.7 \%$ & Kurang \\
$\mathbf{2}$ & II & $82.3 \%$ & Baik & $80.4 \%$ & Baik \\
\multicolumn{2}{r}{ Rata-rata } & $80 \%$ & Cukup & $70 \%$ & Cukup \\
\hline
\end{tabular}

Persentase aspek afektif siswa tanggung jawab meningkat dari 78,4\% menjadi $82.3 \%$ dengan rata-rata persentase $80 \%$. sedangkan kerja sama meningkat dari 59,7\% menjadi 80,4\% dengan rata -rata persentase $70 \%$. Hal ini dapat disimpulkan bahwa pembelajaran IPA dengan menggunakan model make a match dapat meningkatkan aspek afektif siswa dalam proses pelaksanaan pembealajaran. Peningkatannya terlihat untuk masing- masing yang diamati dari Siklus I dan siklus II.

Hal tersebut karna siswa terbiasa dalam proses pembelajaran yang menggunakan model make a match Peningkatan aspek afektif siswa dalam proses pelaksanaan pembelajaran disebabkan peneliti sudah bisa melaksnaan pembelajaran IPA dengan menggunakan model Make A Match. berdasarkan hal diatas dapat disimpulkan afektif siswa dalam proses pembelajaran dengan model Make A Match dapat meningkat, karna proses pembelajaran menjadi lebih menarik, siswa bisa bekerja sama dengan temanya dalam proses pembelajaran IPA.

\section{SIMPULAN DAN SARAN}

Berdasarkan hasil penelitian yang diperoleh pada siklus I dan siklus II yang telah dilaksanakan, maka dapat diambil kesimpulan sebagai berikut: (1) Hasil belajar siswa aspek kognitif siswa kelas IV meningkat dalam memahami materi yang diberikan oleh guru dengan menggunakan model make a match di SDN 12 Api-Api yaitu persentase ketuntasan hasil belajar siswa 58,8\% pada siklus I meningkat menjadi $82,4 \%$ pada siklus II, (2) Hasil belajar siswa aspek afektif siswa kelas IV meningkat tanggung jawab dan kerja sama dengan menggunakan model make a match di SDN 12 Api-Api yaitu persentase ketuntasan hasil aspek (tanggung jawab) 78,4 \% pada siklus I meningkat menjadi 82,3\% pada sklus II rata- rata persentase $80 \%$, dan (3) Kerja sama 59,7 \% pada siklus I meningkat menjadi 80,4 \% pada siklus II rata- rata persentase aspek( kerja sama) 70\%. Dari perbandingan kedua siklus tersebut terdapat peningkatan, hal ini berarti bahwa aspek afektif (tanggung jawab dan kerja sama) siswa pada pembelajaran IPA sudah meningkat.

Berdasarkan hasil penelitian, disarankan kepada kepala sekolah agar dapat memberikan fasilitas kepada guru untuk dapat meningkatkan hasil belajar siswa, kepada para guru agar dapat memanfaatkan metoda mengajar sesuai dengan kebutuhan siswa dan sesuai dengan materi pelajaran. Kepada peneliti selanjutnya agar dapat memantaafkan Model make a match ini ke ruang lingku yang lebih luas. 


\section{DAFTAR RUJUKAN}

Agustina. (2012). Bidang Studi untuk Guru Kelas Sekolah Dasar. Padang: Universitas Negeri Padang. Ahmadi, Iif Khoiru, dkk. (2011). Strategi Pembelajaran Sekolah Dasar. Jakarta: Prestasi Pustaka. Aly dan Rahma. (2011). Ilmu Alamiah Dasar. Jakarta: Bumi Aksara.

Arikunto, Suharsimi, dkk. (2012). Penelitian Tindakan Kelas. Jakarta: Bumi Aksara.

Daryanto. (2014). Pendekatan Pembelajaran Saintifik Kurikulum 2013. Yogyakarta: Gava Media.

Depdiknas. (2006). Kurikulum Tingkat Satuan Pendidikan (KTSP). Jakarta: Depdiknas.

Desfitri, Rita, dkk. (2008). "Peningkatan Aktivitas, Motivasi dan Hasil Belajar Matematika Siswa Kelas VIII2 MTsN Model Padang melalui Pendekatan Kontekstual". Laporan Pengembangan Inovasi Pembelajaran di Sekolah (PIPS). Padang: FKIP Universitas Bung Hatta.

Dimyati dan Mudjiono. (2009). Belajar dan Pembelajaran. Jakarta: Asdi Mahasatya.

Hamalik, Oemar. (2013). Kurikulum dan Pembelajaran. Jakarta: Bumi Aksara.

Hendri, Wince. (2011). Pembelajaran IPA Kelas lanjut. Padang: Bung Hatta University Press.

Hernawan, Asep. (2007). Strategi Pembelajaran. Jakarta: Universitas Terbuka.

Huda, Miftahul. (2014). Model-Model Pengajaran dan Pembelajaran. Yogyakarta: Pustaka Pelajar

Istarani. (2011). 58 Model Pembelajaran Inovatif. Medan: Media Persada.

Rusman. (2012). Model-model Pembelajaran. Jakarta: Rajawali Press.

Sagala, Syaiful. (2009). Konsep dan Makna Pembelajaran. Bandung: Alfabeta.

Shoimin, Aris. (2014). 68 Model Pembelajaran Inovatif dalam Kurikulum 2013. Yogyakarta: Ar-Ruzz Media. Sudjana, Nana. (2011). Penilaian Hasil Proses Belajar Mengajar. Bandung: Remaja Rosdakarya.

Suprijono, Agus. (2009). Cooperative Learning Teori dan Aplikasi Paikem. Yogyakarta: Pustaka Pelajar.

Susanto, Ahmad. (2013). Teori Belajar dan Pembelajaran di Sekolah Dasar. Jakarta: Kencana Prenada Media Group.

Taufik dan Muhammadi. (2011). Mozaik Pembelajaran Inovatif. Padang: Sukabina Press.

Trianto. (2012). Model Pembelajaran Terpadu. Jakarta: Bumi Aksara.

Wardhani, I.G.A.K., dkk. (2003). Penelitian Tindakan Kelas. Jakarta: Universitas Terbuka. 